\title{
Özofagus skuamoz papillomu
}

Esophageal squamous papilloma

Enver AKBAŞ1, Reskan ALTUN², Serkan ÖCAL², Abdullah Emre YILDIRIM², Murat KORKMAZ², Haldun SELÇUK²

${ }^{1}$ Istanbul Medipol Üniversitesi Tip Fakültesi, Gastroenteroloji Bilim Dall, Istanbul

${ }^{2}$ Başkent Üniversitesi Tip Fakültesi, Gastroenteroloji Bilim Dalı, Ankara

Özofagus skuamoz papillomu, genellikle alt özofagusta soliter bir lezyon olarak görülen, iyi huylu skuamoz epitelyal polipoid bir tümördür. Prevalans oranları çok düşüktür ve 1959'dan bu yana literatürde yaklaşı 250 vaka bidirilmiştir. Kronik mukozal irritasyon ve human papilloma virus enfeksiyonu suçlanan etyolojik nedenlerdir. Tipik özofagus skuamöz papillomunun hiçbir özgün semptomu yoktur. Bizim vakamız kronik dispeptik şikayetleri olan ve endoskopik olarak reflü özofajiti saptanan 51 yaşındaki erkek hasta idi. Endoskopik incelemede özofagus 25. cm'de 3-4 mm'lik polipoid oluşum izlendi. Buradan aldığımız biyopsi örneğinin patolojik inceleme sonucu özofagus skuamoz papillomu olarak geldi.

Anahtar kelimeler: Özofagus skuamöz papillomu, özofagus

\section{GIIRISS}

Özofagus skuamoz papillomu, genellikle alt özofagusta görülen soliter bir lezyon olup sik rastlanmayan iyi huylu skuamöz epitelyal polipoid bir tümördür (1).

Özofagus suamöz papillomunun etiyolojisinde üç ana faktörün neden olabileceği ileri sürülmektedir. Bunlardan birincisi reflü özofajitin kronik irritasyonunun neden olduğu kimyasal hasarlanma, ikincisi mukozal hasarlanmaya aşırı rejeneratif yanıt, üçüncü ve tartışmalı olanı ise human papilloma virusun (HPV) rolüdür. Özofageal skuamoz papillomun doğal seyri bilinmemektedir ve özofagus kanserine yol açıp açmadığı tartışmalıdır $(2,3)$.

Özofagusun skuamoz papillomu literatürde 250 civarında vakanın bildirildiği nadir bir benign tümördür. Endoskopik olarak tanı konulan özofagus papillomunun prevalansı birkaç vaka serisinde \%0.01 ile 0.45 arasında değișen oranlarda bildirilmektedir $(4,5)$.

Tipik özofagus skuamöz papillomunun hiçbir patognomonik bulgusu yoktur. Nadir vakalarda, büyük papilloma veya diffüz özefageal papillomatozis varlı̆̆ında disfajiye yol açabilir $(6,7)$.
Esophageal squamous papilloma is a benign squamous epithelial polypoid tumor and is usually seen as a solitary lesion of the lower esophagus. They have a low prevalence, and about 250 cases have been reported in the literature since 1959. Chronic mucosal irritation and infection with human papilloma virus are proposed etiologies. There are no pathognomonic symptoms for the typical esophageal squamous papilloma. Our patient was a 51 -yearold man who had chronic dyspeptic complaints and endoscopically detected reflux esophagitis. A 3-4 mm sized polypoid formation was seen at the $25^{\prime}$ th $\mathrm{cm}$ of his esophagus during the endoscopic examination. Pathologic inspection of the biopsied specimen taken from this part of his esophagus indicated esophageal squamous papilloma.

Key words: Esophageal squamous papilloma, Esophagus

Özofagus skuamöz papillomu endoskopik olarak genellikle tek, yuvarlak, normal mukozadan kabarık, sesil formasyonda ve çevre dokudan iyi ayırt edilen bir yapıdadır. Boyutları 2 mm'den 20x50 mm'ye kadar değişmesine rağmen ortalama 5-6 mm civarındadır. Açık pembe renkte ve yumuşak dansitede görülme eğilimindedir (8).

Patoloji peparatlarında önemli tanı koydurucu özelliği artmış skuamöz hiperplaziyle birlikte fibrovasküler ana yapının görülmesidir.

\section{OLGU SUNUMU}

Başkent Üniversitesi Tıp Fakültesi Hastanesi Gastroenteroloji polikliniğine kronik dispeptik yakınmalarla başvuran 51 yaşındaki erkek hastaya üst gastrointestinal sistem endoskopisi yapılırken özofagus 25. cm'de 3-4 mm boyutlarında normal mukozadan kabarık, üzeri açı pembe renkli polipoid oluşum tespit edildi.Bu oluşum büyük biyopsi forsepsiyle tamamen çıkarıldı ve patoloji laboratuvarına gönderildi. İşleme bağlı herhangi bir komplikasyon gözlenmedi. Hastada ayrıca özofagus alt uçta LA Evre B özofajit tesbit edildi. Materyalin patolojik incelemesi özofagus skuamoz papillomu olarak geldi. 

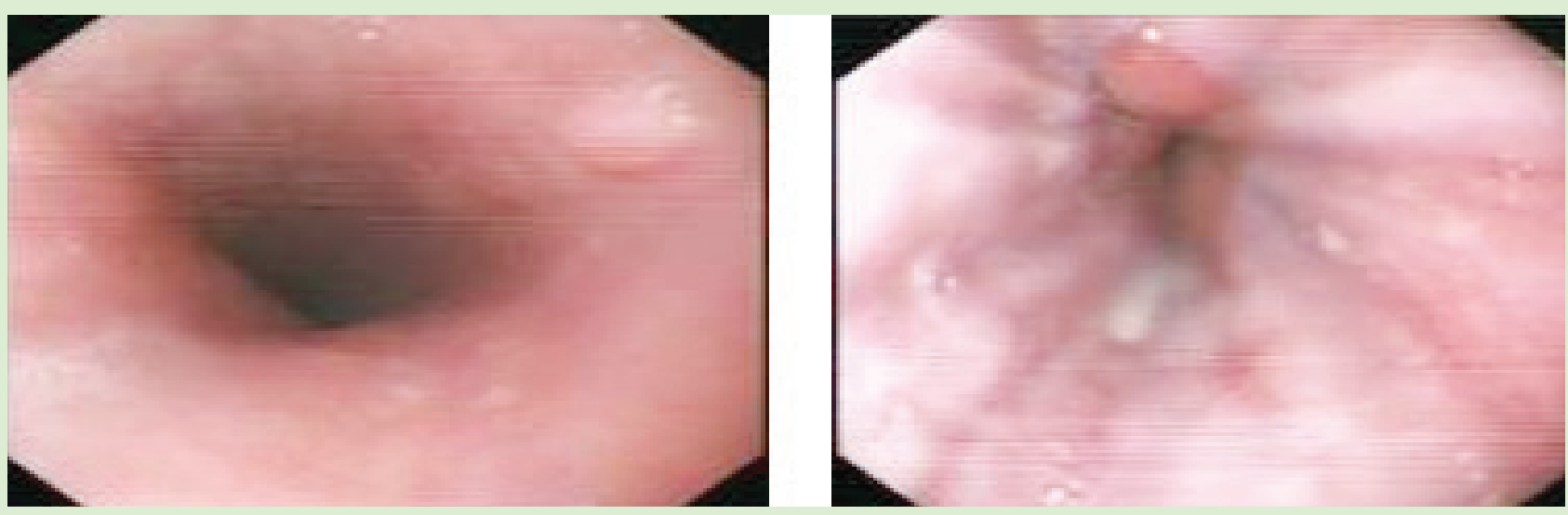

Resim 1. Özofagusta skuamöz papillom görünümü ve LA-B evresi reflü özofajit.

\section{TARTISMA}

Özofagus skuamoz papillomu, artmış sayıda skuamoz hücrelerin ve küçük kan damarlarını da içeren ana bağ dokunun histolojik olarak parmaksı çıııntılarıyla karakterize benign epitelyal bir lezyondur. Insidansı endoskopi serilerinde \%0.01 ile 0.45 arasında değissirken genel popülasyondaki insidansı otopsi serilerinde \%0.006 ile 0.04 arasında değişmektedir $(4,5)$.

Patogenezi tam bilinmemekle beraber iki teori ileri sürülmektedir. Bunlardan ilki inflamatuvar durumlar olup papillomların yaklaşı \% 70'inin distal özofagusta olması bu teoriyi desteklemektedir. Reflü özefajit, nazogastrik tüp ve özofagusun bujilerle dilatasyonlarının neden olduğu mukozal irritasyonlar bu grupta sayılmaktadır. Hayvan çalışmalarinda benzopyren ve nitrozaminlerin neden olduğu kostik

\section{KAYNAKLAR}

1. Katsanos KH, Christodoulou DK, Tsianos EV. Esophageal squamous papilloma. Ann Gastroenterol 2005;18:456-7.

2. Sablich R, Benedetti G, Bignucolo S, Serraino D. Squamous cell papilloma of the esophagus. Report on 35 endoscopic cases. Endoscopy 1988;20:5-7.

3. Szanto I, Szentirmay Z, Banai J, et al. [Squamous papilloma of the esophagus. Clinical and pathological observations based on 172 papillomas in 155 patients]. Orv Hetil 2005;146:547-52.

4. Mosca S, Manes G, Monaco R, et al. Squamous papilloma of the esophagus: long-term follow up. J Gastroenterol Hepatol 2001;16:857-61.

5. Plachta A. Benign tumors of the esophagus. Review of literature and report of 99 cases. Am J Gastroenterol 1962; 38:639-52.

6. Quitadamo M, Benson J. Squamous papilloma of the esophagus: a case report and review of the literature. Am J Gastroenterol 1988;83:194201.

7. Fernandez-Rodriguez CM, Badia-Figuerola N, Ruiz del Arbol L, et al Squamous papilloma of the esophagus: report of six cases with longterm follow-up in four patients. Am J Gastroenterol 1986; 81:1059-62.

8. Carr NJ, Monihan JM, Sobin LH. Squamous cell papilloma of the esophagus: a clinicopathologic and follow-up study of 25 cases. Am J Gastroenterol 1994;89:245-8. mukozal hasarların papillomalara neden olduğu gösterilmiştir $(9,10)$. Resim l'de bu hastaya ait özofaus squamöz papillomu ve Los Angeles -B evresi reflü özofajit gözükmektedir.

Bütün veriler bunu göstermese bile HPV'nin özofageal papillomaların oluşumundaki rolünü destekleyen çalışmalar vardır. HPV'li olgularda yapılan bazı çalışmalarda \%21 ile \%46 oranında özofageal papilloma bulunmuş iken bazı çalışmalarda bu oran \%5'ten daha az bulunmuştur (11-15).

Hiçbir özgün semptomu olmayan özofagus papillomları nadir vakalarda büyünce veya çok sayıda olunca disfajiye neden olabilirler.

Özofagus yassı hücreli karsinomuna dönüşümleri konusu tartışmalıdır.

9. Nakamura T, Matsuyama M, Kishimoto H. Tumors of the esophagus and duodenum induced in mice by oral administration of N-ethyl-N'-nitro-N-nitrosoguanidine. J Natl Cancer Inst 1974;52:519-22.

10. Dunham LJ, Sheets RH. Effects of esophageal constriction on benzo(alpha)pyrene carcinogenesis in hamster esophagus and forestomach. J Natl Cancer Inst 1974; 53:875-81.

11. Syrjanen KJ. HPV infections and oesophageal cancer. J Clin Pathol 2002;55:721-8.

12. Chang F, Janatuinen E, Pikkarainen P, et al. Esophageal squamous cell papillomas. Failure to detect human papillomavirus DNA by in situ hybridization and polymerase chain reaction. Scand J Gastroenterol 1991;26:535-43.

13. Carr NJ, Bratthauer GL, Lichy JH, et al. Squamous cell papillomas of the esophagus: a study of 23 lesions for human papillomavirus by in situ hybridization and the polymerase chain reaction. Hum Pathol 1994;25:536-40.

14. Poljak M, Orlowska J, Cerar A. Human papillomavirus infection in esophageal squamous cell papillomas: a study of 29 lesions. Anticancer Res 1995; 15:965-9.

15. Politoske EJ. Squamous papilloma of the esophagus associated with the human papillomavirus. Gastroenterology 1992;102:668-73. 